\title{
Meaning of Happiness in Children: an Exploratory Study
}

\author{
Rabmatika Kurnia Romadhani ${ }^{1}$ \\ ${ }^{1}$ Department of Psychology, Universitas Negeri Yogyakarta, \\ Jl. Colombo No. 1 Karang Malang Sleman, Yogyakarta \\ 1rahmatika@uny.ac.id
}

\begin{abstract}
The aim of this research was to explore what makes children happy. The study was a survey on the number of 64 elementary students. An open-ended questionnaire was used to learn what makes children happy. The data was analyzed using preliminary coding, categorization, axial coding, and selective coding. The respondents' answers were analyzed using descriptive analysis. Result showed that there were two elements of the source of children happiness, those are (1) Self-fulfillment (95.54\%) consisting of doing activity, doing hobby, leisure time, achievement, gift; (2) Relations with others $(4.46 \%)$ consist of relations with family and friends. This study gave insight that selffulfillment is an important source of happiness in children. This study shows that all are nothing but social engagement.
\end{abstract}

Keywords: Happiness; Children; Self-Fulfillment

\section{Introduction}

Happiness, also known as subjective well being, is defined as an individual's assessment of his life that often experiences pleasant emotions than unpleasant emotions (Diener, 1984; (Diener, Suh, Lucas, \& Smith, 1999). Basically everyone wants to be happy (Diener, 1984). Argylle, 2001) because happiness is a predictor of quality of life (Haller \& Hadler, 2006) and happiness is important (Lyubormrsky, King, \& Diener, 2005; Boven, 2005). People who are not happy tend to experience depression more easily, suicide, anxiety, and show poor work performance and relationships (Ruebenstein, Heereen, Housman, Rubin \& Stechler in Santrock, 2012). Another theory also states that happiness is a goal (Lu and Gilmour, 2004). Some people even make happiness as a life goal (Chan \& Lee, 2006). Everyone at least once a day thinks about happiness (Lybomirsky \& Sheldon, 2005).

Happiness is one of the greatest motivations for human behavior (Diener, 2009). But in several decades, psychologists have explored more about unhappiness and have ignored happiness (Diener, 2009). The literature on happiness focuses on why and how humans live their lives in a positive way, both cognitive and affective.

Happiness consists of an individual's evaluation of his life, including positive affect, rarely feeling negative emotions, and life satisfaction. Research from Tov and Diener (2009) states that psychological well-being can be compared between cultures, but there are specific patterns that differentiate well-being from one culture to another. Welfare is an immaterial concept, welfare is an inner concept of mind, where welfare is the fruit of one's thinking. Welfare cannot be measured from the ownership of material things. There are people who are considered by other people to have excess material and are considered prosperous, but instead feel that they are not. The opposite is also true. A person is seen as less materially, but as long as he feels prosperous, then he is also prosperous (Diener, Lucas, \& Oishi, 2005). 
Based on this explanation, it shows that happiness is an interesting thing to learn. Research on happiness in Indonesia has been conducted several times. However, the research conducted is more of an explanatory and confirmatory research (Primasari \& Yuniarti, 2012). For example, research on adolescent happiness is evaluated based on materialism and dignity (Purnama \& Hastjarjo, 2006), happiness is evaluated from self-acceptance and social support (Sumarno, 2005). However, from the results of the researchers' observations, there has been no research that discusses children's happiness in an exploratory and specific way to raise Indonesian children. So far, research on happiness in children is still focused on research in the west, even though happiness is a special thing, very influenced by culture. Therefore, this study aims to reveal what makes Indonesian children happy?

\section{Methods}

\section{Participants}

The participants of this study consisted of 64 fifth grade students of elementary schools in Yogyakarta.

\section{Research instrument}

The instrument used in this study was an open ended questioner. The question given is that participants are asked who can make them happy, and what situations are the happiest.

\section{Data Analysis}

The data were analyzed through several stages, namely preliminary coding, categorization, axial coding, and selective coding. The categorization process is carried out by combining similar answers from the participants. The categorization process was carried out from a large categorization, then continued with smaller categories. After that, the process is continued by carrying out axial coding, which is combining several themes that have emerged, until axial coding that is in charge of several categories appears. After axial coding emerged, the process was continued with selective coding, which was combining the results of axial coding that were similar.

In the early stages of coding, researchers should be familiar with data and responses from participants in order to facilitate the categorization process (Tukiran, 2008). This stage has been carried out by the researcher before the researcher carries out the categorization process. The analysis was carried out by dividing the research variables into several categories based on a frequency table (Effendi \& Manning, 2008).

\section{Findings and Discussion}

Based on the results of data categorization, it can be seen that what makes children happy at the end consists of five things, namely activity (70.54\%), getting something $(12.50 \%)$, playing with technology (8.04\%), being affiliated $(4.46 \%)$, had special days $(2.68 \%)$, and achieve something $(1.79 \%)$.

Table 1. Sources of happiness in late childhood $(\mathrm{N}=64)$

\begin{tabular}{cc}
\hline Category & $\%$ \\
\hline Activity & $70.54 \%$ \\
Receives something & $12.50 \%$ \\
Technology & $8.04 \%$ \\
Affiliation & $4.46 \%$ \\
Special day & $2.68 \%$ \\
Achievement & $1.79 \%$ \\
\hline Total & $100.00 \%$ \\
\hline
\end{tabular}

Based on data analysis, it can be seen if the participants feel happy when they carry out activities / activities. Activities in question such as when they do their hobbies, exercise, go out, play and travel. When doing this, participants stated that they felt happy, relieved sadness, and 
could interact with other friends, and be released from tension.

Getting something is one of the things that makes them happy. They are happy when they get gifts, get good news, and get money. When you get something, participants feel loved, feel important. In addition, by being given something, participants are happy because they have something new. Participants are also happy when they can play gadgets, have wifi and can play laptops. When they can play with a device, they are happy because playing with a device is fun and not boring, can win certain levels, and can follow the chat of their friends, when discussing things that are currently being discussed.

Some participants feel happy when they are not scolded, meet relatives, are loved by their parents, and make friends and make their parents happy. They are happy when they are not scolded, because when they are scolded they feel unloved, and the anger they give feels scary. Some said they were happy when they got good grades, won, and were praised by their teachers. When they get good grades, participants are happy because it can please their parents, when parents are happy, they feel loved, and when teachers give praise, they feel they are important. One person claims to be happy when he has a birthday. When it was a birthday, participants felt important, and felt special, then received many gifts, and were visited by many friends. The event of doing and getting something is a source of happiness for children. They feel happy when they can do what they love, and have something. They feel valued, loved, understood, and feel special. This makes him less lonely and important.

Based on the data above, it can be concluded that children feel happy when they feel full (self fulfillment). This study found that one source of happiness for children is when they feel whole or fulfilled. Feeling full is translated into several things such as getting certain achievements, making achievements, fun activities such as traveling, vacations, and playing. Of the 64 participants, 70.54\% said what makes them happy is when they can play, exercise and do their hobbies. When getting something becomes fun for children. When children get something they feel they have new things, feel important, special, and increase selfesteem. Participants who answered received gifts as happy things in the amount of $12.50 \%$. As many as $8.04 \%$ of participants were happy when they could play with their device. Furthermore, $1.76 \%$ interpreted happiness when they managed to get certain achievements. Meanwhile $2.68 \%$ are happy when having a special day. When totaled, the participants who interpreted happiness as when they felt full were $95.54 \%$. Second, participants interpret happiness when dealing with other people. Consists of relating to family, friends, and teachers. As many as $4.46 \%$ of participants interpret happiness as the time when they are loved by their parents, make friends, chat, meet relatives, and gather with family.

\section{Discussion}

The results of this study indicate that feeling full or self-fulfillment is the factor that most contributes to children's happiness. Doing fun activities brings fun, pride, and the opportunity to do hobbies. Getting certain accomplishments or achievements makes children feel important and proud of themselves. In addition, the achievements achieved were not only for themselves, but also a form of respect for their parents. Likewise, doing fun activities, not only for themselves, but by doing activities together with other people, children feel this as a time to strengthen relationships with friends. Uchida, Norasakkunkit, and Kitayama (2004) explain that personal happiness can lead to environmental jealousy. Asian people perceive happiness as something more communal. 
Relationships with other people, such as family and friends, are interpreted as cherishing and cherishing events. Family is an important factor of happiness for children. The family is their place to take refuge, ask for something, and the family is the people they can trust. The family is also a source for them to learn, interact with, and to help them when experiencing difficulties. Relationships with friends contribute to children's happiness because friends can accompany them to play, share, and provide support. Having friends also keeps them from feeling lonely.

Family and friends make them feel loved and cherished. Loving and being loved is important to them because it makes them feel important, more confident, feel understood, increases selfesteem, and can reduce sadness. This is in line with research conducted by Primasari and Yuniarti (2012) which states that relationships with other people are a source of happiness. Relationships with other people become happiness because they feel loved and loved. In line with this, research conducted by Uchida, Noraskkunkit, and Kitayama (2004) found that Asian countries define happiness more as communal happiness. Asian communities are more focused on bonds with one another. Happiness for Asian culture is being together. Based on the data obtained, it can be concluded that the source of happiness in children is not individual, and cannot be separated from the presence of other people, especially family.

The results of this study are in line with the findings of a study conducted by Irma (2014) which states that the source of happiness in children consists of three things, namely relationships (friends and family), recreation (sports and sightseeing), material things (gifts and money). . Children conceptualize happiness as a reflection of relationships with others. Previously in the introduction it was explained that happiness is unique and influenced by culture, but from this study it turns out that happiness between Indonesian and African children has something in common.

\section{Conclusion}

The findings from this study found that self-fulfillment is important for children. Family remains an important source of happiness, but self-fulfillment is the main thing for children. The conclusions of this research can be seen in the figure below.

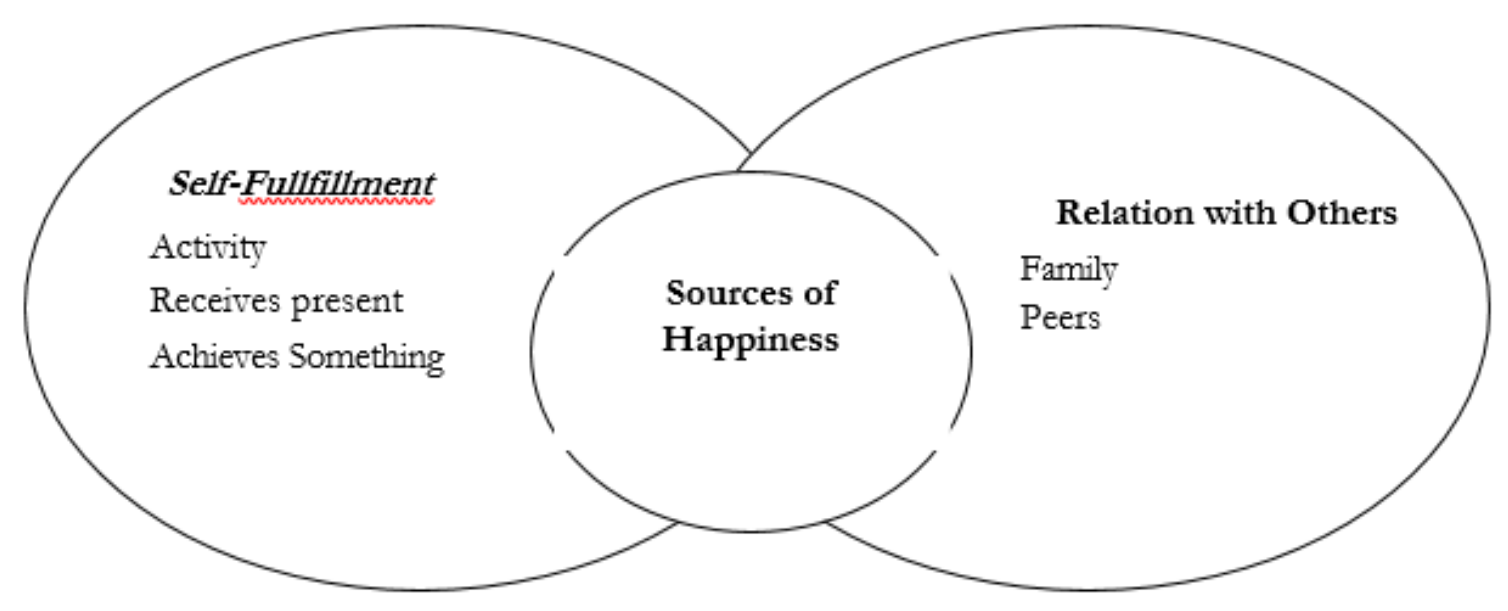




\section{References}

Argylle, M. (2001). The psychology of happiness. New York: Routledge.

Boven, V. L. (2005). Materialism and the pursuit of happiness. Review of general psychology, 2, 132-142.

Diener, E. (1984). Subjective wellbeing. Psychological Bulletin, 95, 542-575.

Diener, E., Suh, E. M., Lucas, R. E., \& Smith, H. (1999). Subjective well being: Three decades of progress. Psychological Bulletin, 125, 276-302.

Haller, \& Hadler. (2006). How social relation and structures can produce happiness and unhappiness: An international comparative analysis. Social Indicator Research: Springer.

Irma, E. (2014). In pursuit of Happines: How some young south African Children construct Happiness. Journal Of Psychology in Africa. 18: 81-87

Lyubormrsky, S., King, L., \& Diener, E. (2005). The benefit of frequent positive affect: Does Happpiness lead to success. American Psychological Association Psychology Bulletin, 131(6), 803-855.

Primasari, A., \& Yuniarti, K. W., (2012). What make teenagers happy? An exploratory study using indigenous psychology approach. International Journal of Research Studies in Psychology. 1, 53-61. DOI: $10.5861 /$ ijrsp.2012/v/li2.80

Uchida, Y. (2004). Cultural constructions of happiness: Theory and empirical evidence. Journal of Happiness Studies, 5, 223-239. Doi: 10.1007/s10902004-8785-9 